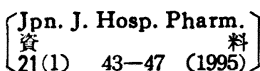

メチシリン耐性黄色ブドウ球菌における消変剤耐性株の分布

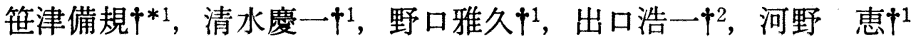

東京薬科大学第二微生物学教室 ${ }^{1}$

東京総合臨床検査センター研究部 †2

\title{
Distribution of Antiseptic-resistant Strains in Methicillin-resistant
} Staphylococcus aureus

\author{
MASANORI SASATSU ${ }^{* 1}$, KeIICHI ShIMIZU ${ }^{+1}$, NoRIHISA NOGUCHI ${ }^{+1}$, \\ KOICHI DEGUCHI ${ }^{2}$ and MEgUMI KONO ${ }^{1}$ \\ Department of Microbiology, Tokyo College of Pharmacy ${ }^{1}$ \\ Section of Studies, Tokyo Clinical Research Center $\dagger^{2}$
}

(Received August 3, 1994

(Accepted October 20, 1994)

\begin{abstract}
One-hundred strains of methicillin-resistant Staphylococcus aurzus (MRSA) isolated from hospitals located in different areas in Japan were tested for antiseptic-resistance and the possession of transferrable antiseptic-resistant plasmid. The coagullase types of MRSA strains were type II (74\%), type N (11\%), type VI (8\%), type III (2\%) and non-type (5\%). Sixtyone strains were penicillinase-producing and 39 were non-producing. Antiseptic-resistant MRSA strains were isolated from 50 hospitals in different areas in Japan. The transferrable gentamicin-resistant plasmids were detected from 23 of the harboured strains. The antiseptic-resistant determinant was located on the transferrable gentamicin-resistant plasmid in 12 of the 23 strains. These 12 strains harbouring the transferrable antiseptic-resistant plasmid were isolated from all areas of Japan except for Hokkaido and Okinawa. The antiseptic-resistant strain and the strains harbouring the transferrable antiseptic-resistant plasmid were found not to exist in any specific hospital or area in Japan.
\end{abstract}

Keywords—-methicillin-resistant Staphylococcus aureus, MRSA, antiseptic-resistance, transferrable plasmid, antiseptic-resistant plasmid, distribution

\section{緒 論}

わが国に怙ける，メチシリン耐珄黄色ブドウ球 菌 (MRSA) による院内感染は依然として大きな 医療問題の一つである.その原因として, MRSA は病院内の環境に長期間生存できること ${ }^{1)}$, 多く の抗生剤に耐性を示す多剂酎性菌であることなど

†1 東京都八王子市堀之内 1432-1；1432-1, Horinouchi, Hachioji-shi, Tokyo, 192-03 Japan

$\dagger^{2}$ 東京都足立区千住仲町 14-4；14-4, Senju-Nakamachi, Adachi-ku, Tokyo, 120 Japan
が報告されている ${ }^{2,3)}$ また，我々はMRSAの中 には消毒剤にも耐性を示す菌株が存在することを 報告し ${ }^{4)}$ ，このような消毒剤耐性機構について検 討を行ってきた，その結果，消毒剤耐性遺伝子 $e b r$ は伝達性プラスミド上に存在する比較的小さ な遺伝子（596塩基）であり，107アミノ酸からな る分子量 11,700 蛋白質をコードしている5). 両 端にインバーテットリピート配列を持つトランス ポゾン様構造をしており, 耐性機構は細胞からの 薬物の排出である ${ }^{6)}$. 遺伝子の重複により高度耐 珄化するなどの性質を示す6) $e b r$ 遺伝子を持つ 
MRSA 株は各種消毒剤，色素系薬剤，防腐郕など に幅広く耐性を示し，カルシウムチャンネルブロ ッカー，カルモジュリン阻害剤により，消毒剤耐 性は阻害されることなどが明らかになっだ)。さ らに，このような消毒剤耐性株を用いた各種消毒 剂の評価についても報告してきた8,9).

消毒剂耐性 MRSA の存在は, 医療の現場では 重要な問題である。しかし，このような消毒剤耐 性 MRSA 株はある限られた地域に存在するの か，あるいは全国的に分布しているのかは未だ明 らかでない，そこで本論文ではわが国における消 毒剂耐性 MRSA 株の分布，並びに伝達性消毒剂 耐性プラスミドの分布について全国的な調査を行 った。

\section{実験材料および方法}

\section{1. 使用菌株}

実験に使用したメチシリン耐性黄色ブドウ球菌 (methicillin-resistant Staphylococcus aureus : MRSA）株は東京総合臨床検查七ンターで分離さ れた菌株であり，北海道から沖繩まで分離された 地域, 扣よび病院がかたよらない100 株を選択し た，消毒剤耐性の標準株として用いた消毒剂高度 耐性N20株は1989年に分離され，伝達性プラスミ ド pTZ22 上に消毒剤耐性遺伝子を持っている6). 消毒剂低度耐性株 L 20 A は1985年分離され，伝達 性プラスミド pTZ20 上に消毒剂耐性遺伝子を持 っている4). RN2677 株は修飾および制限マイナ スのノボビオシンおよびリファンピンン耐性株で あり，伝達実験の受容菌として用いられた ${ }^{4,6)}$.

\section{2. 薬剤感受性の測定}

薬剤感受性は日本化学療法学会標準法に従い寒 天平板希釈法により測定した ${ }^{10)}$. 培地は MuellerHinton agar (Difco Laboratories, Detroit, MI）を用いた。使用した抗菌郕はメチシリン (DMPPC)，オキサシリン (MPIPC), ベンジル ペニシリン (PCG), セファゾリン (CEZ), セフ メタゾール $(\mathrm{CMZ})$, ゲンタマイシン $(\mathrm{GM})$, カ ナマイシン (KM), トブラマイシン (TOB), ， ルフロキサシン $(\mathrm{NFLX})$, エリスロマイシン $(\mathrm{E}$ $\mathrm{M})$, クロラムフェニコール (CP), テトラサイク
リン (TC) である。 また，消毒剤感受性测定の指 標として，エチジウムブロアイド (EB)，および 塩化ベンゼトニウム（BT）を用いた.

\section{3. 接合伝達実験}

プラスミドの接合伝達実験は Schaberg ら （1982）の才法に準じ，フィルターィイティング 法により行っだ11. 伝達株の選択には GM $5 \mu \mathrm{g}$ / $\mathrm{ml}$, ノボビオシン (NB) $5 \mu \mathrm{g} / \mathrm{ml}$, リファンピシ ソ (RFP) $5 \mu \mathrm{g} / \mathrm{ml}$ 含有のトリプトソイ寒天培地 （栄研化学, 東京）を用いた。

\section{4. プラスミド DNA の検出}

プラスミド DNA の抽出には Promega 社の Magic $^{\mathrm{TM}}$ Minipreps DNA Purification Systemを用いた．プラスミド DNA の検出は通常の アガロースゲル電父泳動法により行った.

\section{5. コアグラーゼ型とペニシリナーゼ産生}

コアグラーゼ型はデンカ生研のニアグラーゼ型 別キットを用いた。 また，ベニシリナーゼ㳯生の 有無はファイザー製薬株式会社より分少された $\beta$ ラクターーゼ検出用ディスク「ß-check」を用い た.

\section{結果と考察}

実験に使用した MRSA 株の背系を調べるため に全菌株のコアグラーゼ型, ベニシリナーゼ産生 能，および薬剤感受性について検剖した。

1. コアグラーゼ型とぺニシリナーゼ産生

実験に使用した MRSA 株のコアグラーゼ型を Fig. 1 に, ペニシリナーゼ产生をFig. 2 に示し た. コアグラーゼ型はI型が $74 \% ， \mathrm{~N}$ 型が $11 \%$, VII型が $8 \%$ ，而型が $2 \%$ であり型別不能株が $5 \%$ であり，これまで報告されている紸果之一致して いた ${ }^{3)}$ またへニンリナーゼに闺しては61\%が 産生株であり，39\%が非产生株であった、コアグ ラーゼ型とベニシリナーゼ成生株について地域的 なかたよりは認められなかった。

\section{2. 薬侴感受性}

実騟に使用した MRSA 100 株の MIC 值の分 布を Fig. 3 に示した。测定した抗菌剂のうち, $\mathrm{CP}, \mathrm{TC}$ を除く全ての薬剂に対し $80 \%$ 以上の菌株 が耐性を示した。これらの菌株は各種抗生郕に対 
Non-type $5 \%$

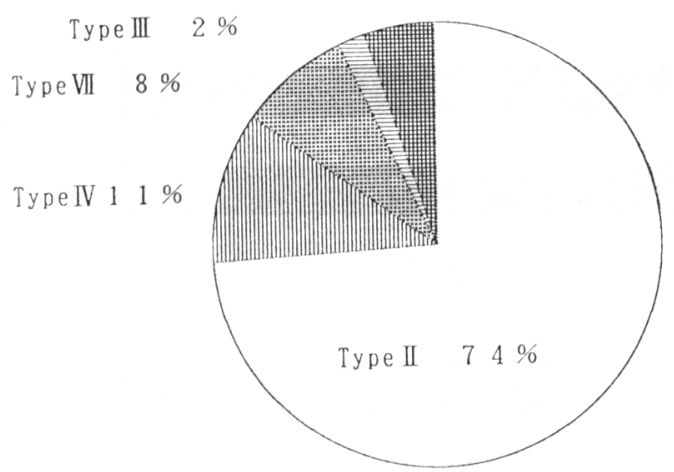

Fig. 1. Coagulase Types of the 100 Strains of MRSA

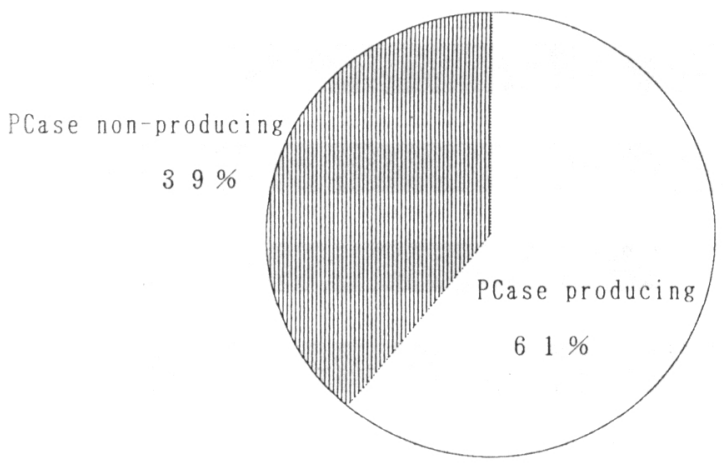

Fig. 2. Ratio of Penicillinase-producing Strains and Non-producing Strains of the 100 Strains of MRSA Penicillinase, PCase.

乙耐性を示す多剂耐性株であった。また，60\%以 上の株がニューキ,ロン郕にも $100 \mu \mathrm{g} / \mathrm{ml}$ 以上の 高度耐性を示した。かつて非常に多からたクロラ ムフェニュール耐性株は10\%しか検出されなかっ た。クロラムフェニコール耐性株が分離されたの は秋田, 栃木, 群馬 ( 2 株), 千葉, 静岡, 愛知, 広帛, 鳥取, 德島であった。ブドウ球菌感染症に 刘し，使われなくなったりロラムフェニコールに 対する耐性株が，これらの地域にどのような理由 で㠫在㐪で存在しているのか興味がもたれる。亦 た，消囸剂耐性の指慓であるエチジウムブロマイ ドに対し約 $50 \%$ の怢が $25 \mu \mathrm{g} / \mathrm{ml}$ 以上の耐性を圭 した。このような消毒剤耐性株が検出された地域
は北海道から沖繩まで全国的に分布していた。し かし, 尚都圈（都内, 千葉, 埼玉, 神奈川) から 分離された菌株が比較的消毒剂耐性を示导割命が 高いことが特徴的であった。

\section{3. 伝達性プラスミド}

伝澾性について調べると結果は Table 1 のご とく，23株よりゲンタマイシン耐性の伝達性ブラ スミドが検出された。これらの菌株からは L20A

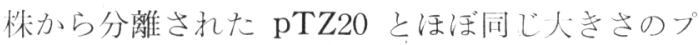
ラスミドDNAが検出された。このうち，12株か らは消毒剂耐性も伝達した。京た 1 株は消毒版高 度耐性であった。伝達性ブラスミドを保们してい る株のコアグラーゼ型は II 型が 17 株 $(74 \%)$, III 型 とVII型が各 2 株 $(9 \%) ， \mathbb{V}$ 型之型別不能怢が各 1 株 $(4 \%)$ であり，全体の菌株のコアグラーゼ型 の分布と一致しており, 特定コアグラーゼ型の菌 株が伝達性ブラスミドを所付しているわ子ではな かった。またペニシリナーゼに関しては, 伝達性 ブラスミド保付株の78\%がペニシりナーセ商生株 であったが，同時伝達は認められなからた。オー ストラリアではべニシリナーゼ座生遗伝おが伝達 性プラスミドに移行した菌株が報告されている が12)，わが国では琴在まで報告されていない。

MRSA の伝详性 GM 耐性プラスミドは汒繩から 東北地方に加汁て広く分布して和り, 特定の菌株 や地域に関係なく全国的に分布していた。消毒剤 耐性を持っている伝達性プラスミドにいても， 九州地方より 4 株, 東北地方ょり 3 株, 関東地方 より 2 株, 中部, 中国, 四国地方上り条 1 株分離 された。北海道と沖繩老除く，全ての地域に分布 しているものと思われる。

消毒剂耐性 MRSA 株の存在は, 矢療現啰に招 いては無視できない問題である。消青剂而性株は 全国 $50 \%$ の病院から分離された。ささらに渻清剂耐 性遺伝子が伀達性ブラスミド上に存在している菌 株も全国12力所の病院から分離されている。消毒 剂耐性遺伝子を持った伝達性ブラスミドが愉出さ れない消毒剂耐性株においては, 淌青剂耐性遺伝 子が染色体上に存在し安定化しているものと思わ れる。消毒剂耐性伝達州ブラスミドを持つ菌株の

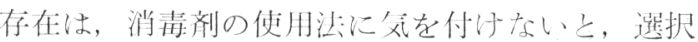




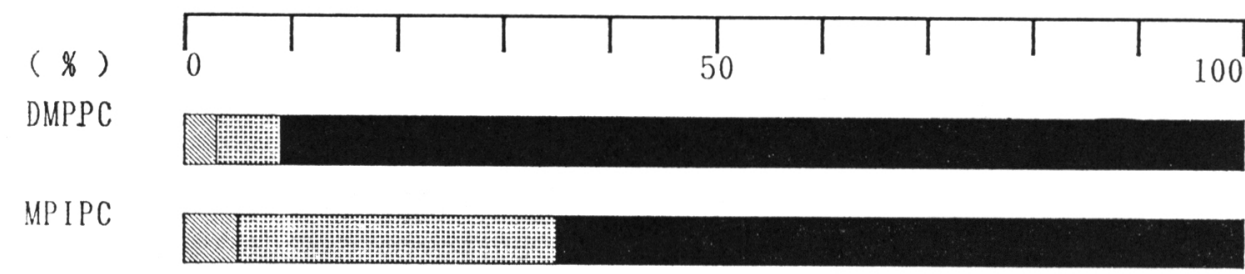

PCG

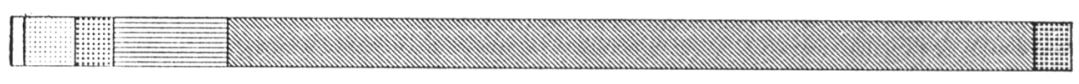

CEZ

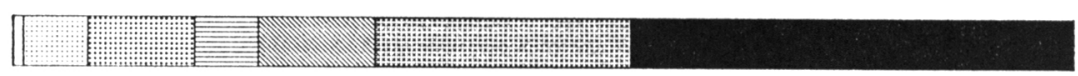

CMZ

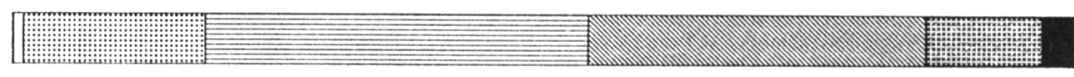

GM

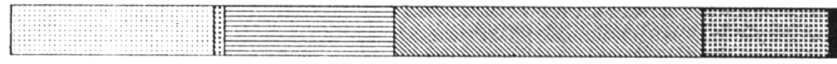

$K M$

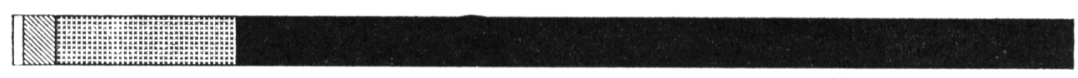

TOB

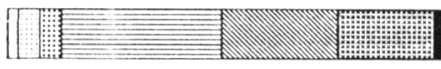

NFLX

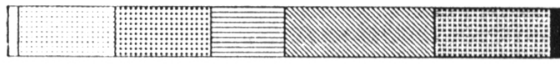

EM

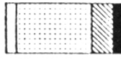

CP

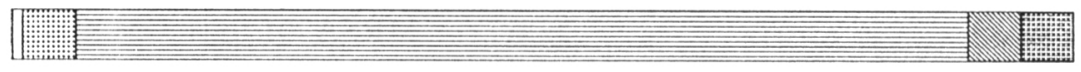

TC

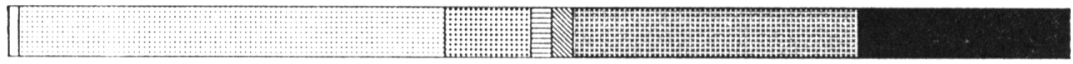

Ethidium bromide

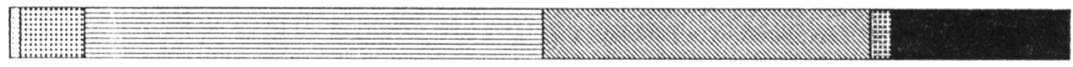

Benzethonium chloride

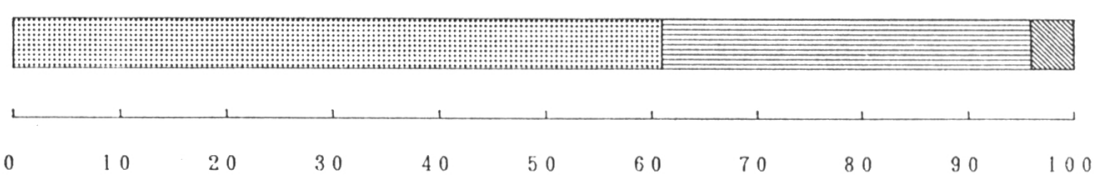

Fig. 3. Distribution of MICs of Antimicrobial Agents against MRSA Strain Tested in This Experiment.
$\square: \leqq 0.1 \mu \mathrm{g} / \mathrm{ml}$,
: $0.2 \sim 0.78 \mu \mathrm{g} / \mathrm{ml}$,
:1.: $: 56 \sim 3.13 \mu \mathrm{g} / \mathrm{ml}$,
: $: 25 \sim 50 \mu \mathrm{g} / \mathrm{ml}$,
跮: $6.25 \sim 12.5 \mu \mathrm{g} / \mathrm{ml}$,
: $\geqq 200 \mu \mathrm{g} / \mathrm{ml}$
필 $: 100 \mu \mathrm{g} / \mathrm{ml}$,

され消毒剂感受性株に消毒剂耐性遺伝子を伝達寸 存在は特定の地域, 特定の病院だけの問題ではな る危険性を示している。消毒剂耐性 MRSA 株の い, 消毒剂の使用時には消毒剤耐性株が完全に殺 
Table 1. Transfer of GM- and Antiseptics-Resistance from MRSA Strans

\begin{tabular}{|c|c|c|c|c|c|c|c|}
\hline Strain & $\operatorname{Res}$ & istar & nce 1 & Marker Transferred & Coagulase Type & Penicillinase $* 1$ & Isolated from *2 \\
\hline ST 4 & GM & KM & T0B & Ant i sept ics $(L) * 3$ & II & - & Fukuoka \\
\hline ST 5 & GM & KM & TOB & Ant i sept ics (L) & II & + & Sai tama \\
\hline ST 7 & GM & KM & TOB & Ant iseptics (L) & II & + & Shi zuoka \\
\hline ST18 & GM & KM & TOB & Ant i sept i cs (L) & II & + & Chiba \\
\hline ST 20 & GM & $\mathrm{KM}$ & TOB & Ant i sept ics (L) & III & + & 0ita \\
\hline ST24 & GM & KM & TOB & Ant i sept i cs (L) & III & - & Saga \\
\hline ST25 & GM & KM & TOB & Ant i sept ics (L) & II & + & Kagawa \\
\hline ST32 & GM & KM & TOB & & II & + & Nagasaki \\
\hline ST33 & GM & KM & TOB & & II & + & Mie \\
\hline ST36 & GM & KM & TOB & Ant i sept i cs (L) & VII & + & Akita \\
\hline ST46 & GM & KM & TOB & Ant i sept ics $(H)^{* 4}$ & III & + & Yamagata \\
\hline ST51 & GM & KM & TOB & & III & + & oki nawa \\
\hline ST52 & GM & KM & TOB & & IV & + & Wakayama \\
\hline ST55 & GM & KM & TOB & & III & + & Tokyo \\
\hline ST60 & GM & KM & TOB & & II & - & Fukuoka \\
\hline ST63 & GM & KM & TOB & & III & + & Kanagawa \\
\hline ST66 & GM & KM & TOB & & VII & + & Nagano \\
\hline ST70 & GM & KM & TOB & Ant i sept ics (L) & III & - & Miyagi \\
\hline ST82 & GM & KM & TOB & & IIII & - & Chiba \\
\hline ST84 & GM & KM & TOB & Ant i sept i cs (L) & II & + & Hi roshi ma \\
\hline ST85 & GM & KM & TOB & & III & + & Miyagi \\
\hline ST90 & GM & KM & TOB & Ant i sept ics (L) & III & + & Fukuoka \\
\hline ST96 & GM & KM & TOB & & II & + & Akita \\
\hline
\end{tabular}

*1: Penicillin-producing strain, + ; non-producing strain, -

*2: Strains were isolated from each prefecture.

*3: Low-level resistance to antiseptics.

*4: High-leverl resistance to ant iseptics.

菌される消毒剤の使用濃度, 使用時問等の条件を 十分に考虑しなければならない。

\section{引用文献}

1) M. Sasatsu, Y. Shibata, N. Noguchi, M. Nagata, M. Murata, Y. Ogata and M. Kono, Microbios, 75, 17-21 (1993).

2）紺野昌俊, “MRSA 感染症のすべて”, 医薬ジャ 一ナル社, 大阪, 1991, pp. 13-33.

3) 橋本 一, Infection Control, 1, 10-15 (1992).

4) M. Sasatsu, Y. Shibata, S. Tamura and M. Kono, Microbios Lett., 43, 105-112 (1990).

5) M. Sasatsu, K. Shima, Y. Shibata and M. Kono, Nucl. Acids Res., 17, 10103 (1989).

6) M. Sasatsu, Y. Shibata, N. Noguchi and M.
Kono, FEMS Microbiol. Lett., 93, 109-114 (1992).

7) M. Sasatsu, Y. Shibata, N. Noguchi and M. Kono, Biol. Pharm. Bull., 17, 163-165 (1994).

8) M. Sasatsu, K. Shimizu, N. Noguchi and M. Kono, Biol. Pharm. Bull., 17, 136-138 (1994).

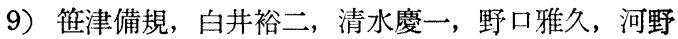
恵, 病院薬学, 19, 516-521 (1993).

10) Japan Society of Chemotherapy, Chemothera$p y, 29,76-79$ (1981).

11) D.R. Schaberg, D.B. Clewell and L. Glatzer, Antimicrob. Agents Chemother., 22, 204-207 (1982).

12) B. Lyon and R. Skurray, Microbiol. Rev., 51, 88-134 (1987). 